\title{
ASSESSMENT OF URBAN SPRAWL USING SHANNON'S ENTROPY AND FRACTAL ANALYSIS: A CASE STUDY OF ATAKUM, ILKADIM AND CANIK (SAMSUN, TURKEY)
}

\author{
Derya OZTURK \\ Department of Geomatics Engineering, Faculty of Engineering, \\ Ondokuz Mayis University, 55139 Samsun, Turkey
}

Submitted 03 Nov. 2015; accepted 05 Sep. 2016

\begin{abstract}
Urban sprawl is one of the most important problems in urban development due to its negative environmental and societal impacts. Therefore, the spatial pattern of urban growth should be accurately analyzed and well understood for effective urban planning. This paper focuses on urban sprawl analysis in the Atakum, Ilkadim and Canik districts of Samsun, Turkey. In this study, urban sprawl was examined over a period of 24 years using Shannon's entropy and fractal analysis based on remote sensing and Geographic Information System (GIS). The built-up areas in 1989, 2000 and 2013 were extracted from Landsat TM/ETM+/OLI images using the maximum likelihood classification method, and urban form changes in the 1989-2013 period were investigated. The Shannon's entropy method was used to determine the degree of urban sprawl, and a fractal analysis method based on box counting was used to characterize the urban sprawl. The results show that Atakum, Ilkadim and Canik experienced important changes and have considerable sprawl and complex characteristics now. The study also revealed that there is no monotonic relationship between Shannon's entropy and fractal dimension.
\end{abstract}

Keywords: urban sprawl, Shannon's entropy, fractal analysis, box-counting, maximum likelihood classification, Landsat.

\section{Introduction}

Understanding urbanization and analyzing urbanization patterns are useful for determining the current and future needs of a region. Addressing these future needs is essential, especially for the management of limited natural resources and the construction of infrastructure. Uncontrolled urbanization allows for urban sprawl in general and leads to serious problems in both short- and longterm infrastructure planning (Sudhira et al. 2004). Urban sprawl is a complex phenomenon and has both environmental and societal impacts (Sun et al. 2007). It causes many problems, such as environmental damage, economic inefficiency and injustice in public and infrastructure services. Therefore, it is not a suitable urban growth pattern (form) for sustainable development (Jat et al. 2008; Marsousi, Lajevardi 2011; Li 2012; Jaeger, Schwick 2014; Hassan, Lee 2015).

Urban sprawl is one of the most discussed topics in urban planning. The factors that cause urban sprawl, the results of urban sprawl and urban policies constitute the main research topics, but studies measuring the forms and characteristics of the sprawl have increased in recent years (Terzi, Kaya 2008). Rapid and economical access to spatial data due to advances in remote sensing and rapid analysis possibilities using Geographic Information System (GIS) technology have resulted in an increase in the study of urban patterns and changes (Duran et al. 2006; Musaoglu et al. 2006; Bhatta 2010; Kaya et al. 2012; Hegazy, Kaloop 2015; Ozturk 2015).

There are many techniques for measuring and mapping urban morphology and urban sprawl, including shape index, contagion index, Shannon's entropy, fractal analysis and Moran's I (Bhatta 2012; Munafo, Congedo 2013; Zeng et al. 2014). With evolving technology, mathematical methods have been introduced in urban analysis, and complex analysis methods have been widely used in form analysis (Kaya, Bolen 2011). Shannon's entropy and fractal analysis have recently been used in urban analysis, especially in studies that integrate remote sensing and GIS (Dewan, Corner 2014). Shannon's entropy is suggested as a measure of spread (Nason 2008). It is one of the most commonly used and one of the most reliable

Corresponding author: Derya Ozturk

E-mail: dozturk@omu.edu.tr 
techniques for the determination of urban sprawl due to its robustness and easy application (Verzosa, Gonzalez 2010; Sarvestani et al. 2011). Shannon's entropy is used to measure the degree of spatial concentration or dispersion of geographic variables among " $n$ " spatial zones. There are several spatial zone division approaches in the literature to calculate entropy values. The most common are administrative boundaries (Sudhira et al. 2003, 2004; Jat et al. 2008; Bhatta 2009; Li 2012), circular buffer zones around the center (Kumar et al. 2007; Sun et al. 2007; Sarvestani et al. 2011; Kiran, Joshi 2013; Hsieh 2013), pie sections (Bhatta et al. 2010a), and a combination of circular buffers and pie sections (Ramachandra et al. 2012; Alsharif et al. 2015; Ramachandra et al. 2015). Buffer zones are created around city centers and a city center is generally determined using one of three basic forms: the geometrical center, the commercial center and the political hot spot (Wu et al. 2013). Entropy can be used to indicate the degree of urban sprawl by examining whether built-up area development in a city is dispersed/sparse or compact (Jat et al. 2008). The dispersion of built-up areas from a city center or road network causes an increase in the entropy value (Tewolde, Cabral 2011). Recently, fractal analysis has emerged as a powerful technique for the analysis of urban morphology and structure (Mcadams 2007). Fractal geometry allows for the analysis of complex processes by overcoming the rigidity of Euclidean geometry and provides an important insights for describing the urban form and characterizing sprawl (Mesev et al. 1995; Hu et al. 2015). Fractal analysis mainly includes the calculation of fractal dimension. There are many different methods for the calculation of the fractal dimension: the topological dimension, Hausdorff dimension, self-similarity dimension, box-counting dimension, capacity dimension, Euclidean dimension, information dimension, and more (Peitgen et al. 2004; de Castro 2006). Box counting is one of the most well-known and most commonly used methods to calculate the fractal dimension (Brown 1995), and it is widely used in studies related to land use, spatial analysis and urban analysis (Shen 2002; Kaya, Bolen 2011). The fractal dimension of a city provides a measure of the extent to which a city fills its two-dimensional area (Torrens, Alberti 2000). In the case of urban sprawl, empty spaces are filled with irregular and self-similar forms (Li 2012), and the urban form shows a complex structure (Terzi, Kaya 2008; Li 2012). The fractal dimension is a useful parameter for the characterization of complexity (de Oliveira et al. 2014) and a higher fractal dimension indicates a more complex geometry ( $\mathrm{Hu}$ et al. 2015). The fractal dimension can be thought of as a space filling measure and fractal dimension of urbanized areas can also be thought of as an indicator of the complexity or dispersion of the urban form. In general, a higher value of a city's fractal dimension indicates a more complex or disperse city (Shen 2002). Therefore, to understand the characteristics of urban growth and to examine urban sprawl, the use of fractal analysis alone or in combination with other methods has become increasingly common (Terzi, Kaya 2008; Li 2012).

Determination of the degree and the form of urban sprawl and understanding the reasons are very important because urban sprawl is a barrier to sustainable development (Jat et al. 2008; Marsousi, Lajevardi 2011; Li 2012; Jaeger, Schwick 2014; Hassan, Lee 2015). Turkey, as a developing country, faces the problem of urban sprawl. Samsun is one of the sections where urban sprawl has become a most significant problem because of the rapid population growth potential. For this reason, a case study in Samsun was conducted to characterize the urban growth pattern of the regions with rapid population growth in Turkey. The first goal of this study is to measure the sprawl and complexity of the adjacent administrative districts of Atakum, Ilkadim and Canik in Samsun, Turkey in the years 1989, 2000 and 2013, during which these districts experienced rapid growth, using Shannon's entropy and fractal analysis based on remote sensing and GIS. In addition, the changes and the causes and effects of the changes over the period 1989-2013 are investigated. The second goal is to determine whether there is a relationship between Shannon's entropy and fractal dimension. To this end, the paper is organized as follows: Section 1 introduces the study area, Section 2 gives a detailed methodological framework of image classification, Shannon's entropy and fractal analysis, Section 3 reports the findings on sprawl, the assessment of Shannon's entropy and the fractal dimension values, and Section 4 evaluates and discusses the results.

\section{Study area: Atakum, Ilkadim and Canik}

Atakum, Ilkadim and Canik are the three districts with the highest population growth rates out of the 17 districts connected to the Samsun Province in Turkey (Fig. 1). Previously, Atakum, Ilkadim and Canik were first-tier municipalities, and they gained district status with Law No. 5747 published in Official Gazette No. 26824 in 2008.

The total area of the districts is approximately $354 \mathrm{~km}^{2}$ for Atakum (Atakum Municipality 2014), approximately $152 \mathrm{~km}^{2}$ for Ilkadim (District Governorship of Ilkadim 2015) and approximately $250 \mathrm{~km}^{2}$ for Canik (District Governorship of Canik 2015). This study focuses on the portion of the Atakum, Ilkadim and Canik Districts with the largest population increase, a high urbanization potential and high urban development. The study area consists of an area of $92.7 \mathrm{~km}^{2}$ consisting of 29 sectors and containing 94.7\% of Atakum's population in Atakum, an area of $60.2 \mathrm{~km}^{2}$ consisting of 52 sectors and containing $98.1 \%$ of Ilkadim's population in Ilkadim and $9.5 \mathrm{~km}^{2}$ area consisting of 16 sectors and containing $80.4 \%$ of Canik's population in Canik (Fig. 1). 


\section{Data and methodology}

In this study, the urban sprawl and urban sprawl changes in the Atakum, Ilkadim and Canik Districts of Samsun were examined. These districts are adjacent and have experienced significant population increases but differ from each other in topographical, areal, and morphological characteristics. These characteristics have contributed to the nodes and routes of transportation networks, construction conditions and hence urban forms. For this reason, these three districts were analyzed separately and compared with each other. Shannon's entropy was used to measure the urban sprawl, and fractal analysis was used to identify the sprawl characteristics. Built-up areas, which are necessary for the detection of urban sprawl, were obtained using Landsat-4 TM from August 2, 1989, Landsat-7 ETM+ from June 13, 2000 and Landsat-8 OLI from September 13, 2013. These images were classified using a maximum likelihood classification method. Because the major concern of the study was urban sprawl, the land use/cover classes were reclassified into built-up and non-built-up for further analysis. Satellite images were downloaded free of charge from the U.S.
Geological Survey Earth Explorer (U.S. Geological Survey 2015). To rectify and classify images and to check the classification results, $1 / 25000,1 / 5000$ and $1 / 1000$ scale maps were used, and to determine the boundaries of the study area, 1/25000 scale administrative boundary maps were used. ENVI 5.1 software (Exelis, Herndon, VA) was used to process and classify the satellite images, and ARIS Grid Editor (ARIS B.V., Utrecht, NL) running on ArcGIS 10.0 software (ESRI, Redlands, CA) was used to enhance the classification results by editing. Shannon's entropy analysis was performed using ArcGIS software, and fractal analysis was performed using ImageJ software (National Institutes of Health, USA), which can be obtained for free from the web (IMAGEJ 2015), and the FracLac plugin (FRACLAC 2015), which runs on ImageJ. Shannon's entropy was used to measure urban sprawl, and fractal analysis was used to understand the changes in the fractal dimension of this sprawl. The main process steps of this study are shown in Figure 2.

In the first phase, Landsat images are classified and reclassified into built-up and non-built-up areas in a
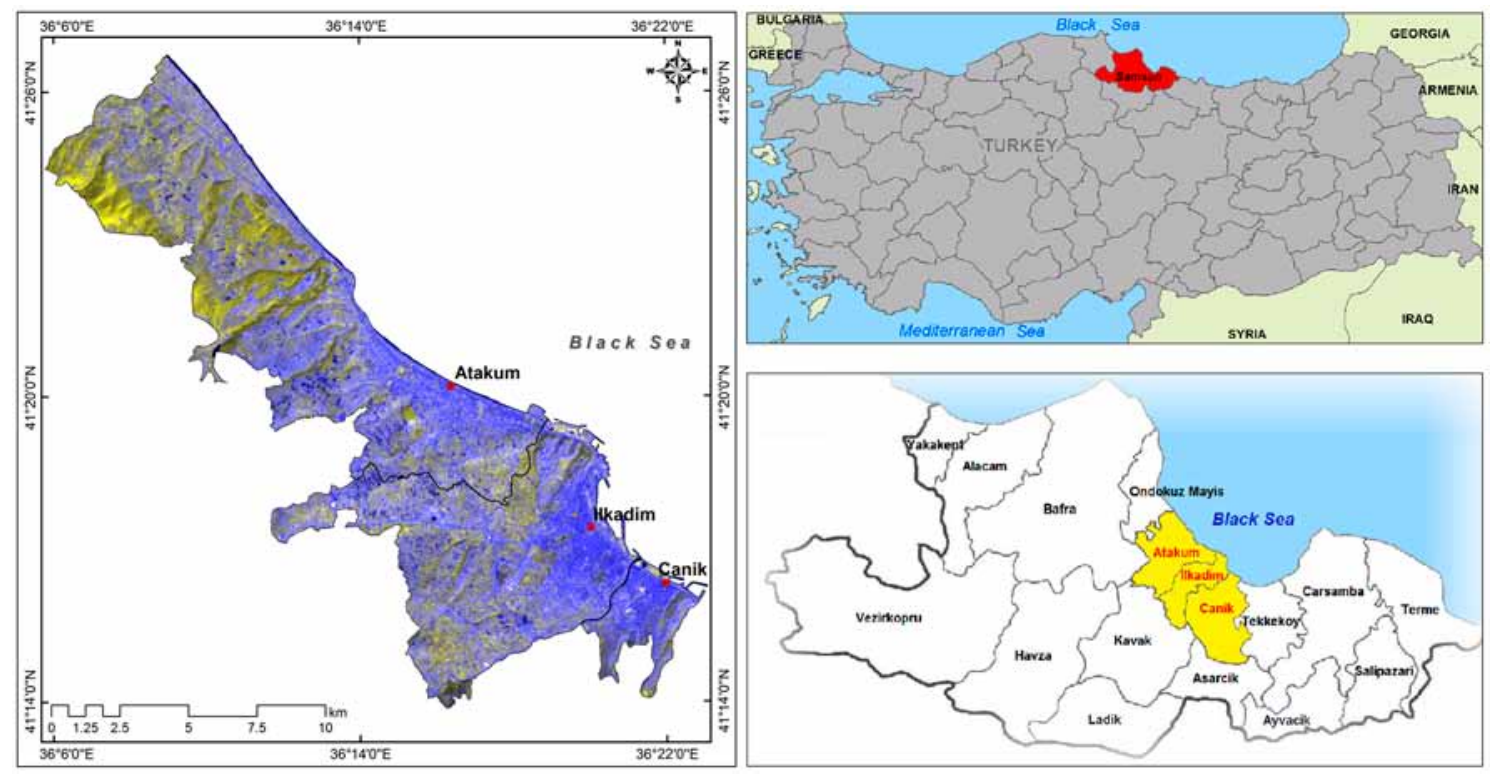

Fig. 1. Location of the study area: the Atakum, Ilkadim and Canik Districts are in the Black Sea Region, Turkey

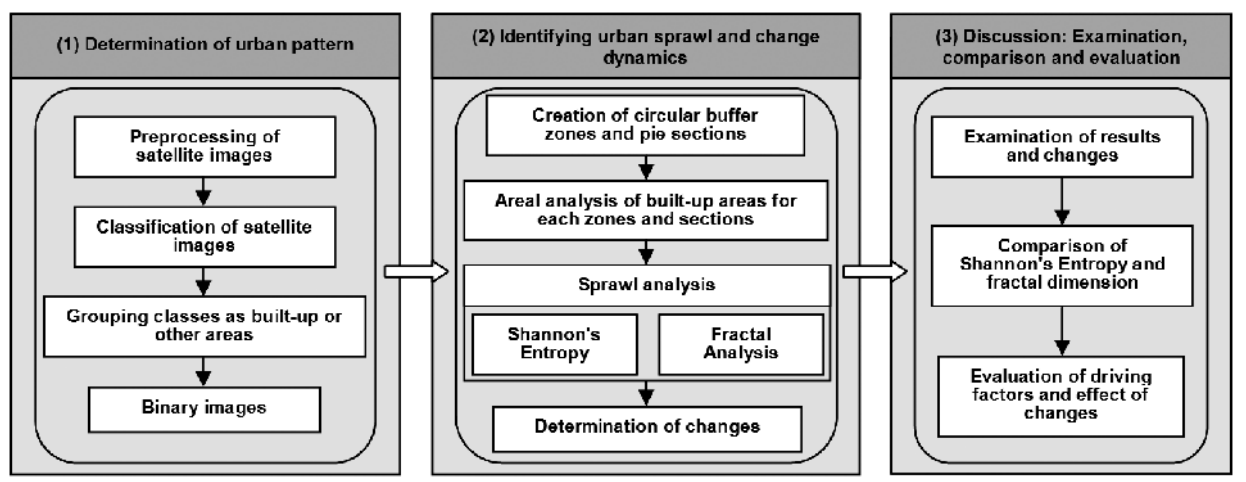

Fig. 2. Flow chart showing the main steps of the study 
binary form. In the second phase, the urban sprawls in 1989, 2000 and 2013 are examined using Shannon's entropy and fractal analysis, and the changes that occurred in the periods 1989-2000 and 2000-2013 are determined. In the final phase, the results are examined and compared, and the reasons for urban sprawl and changes in the sprawl as well as the effects of sprawl are discussed.

\subsection{Image preprocessing and classification}

A rectification process was performed prior to the classification of the Landsat satellite images, and all images were coordinated to the UTM-WGS84 system. First, the satellite image of 2013 was georeferenced using $1 / 25000$, $1 / 5000$ and $1 / 1000$ scale maps; then, the images of 1989 and 2000 were image-to-image geo-referenced using the 2013 image. All of the total mean square errors of the rectification processes were less than 0.5 pixels. The rectified images were classified into four classes, including artificial areas, vegetation areas, open spaces and water spaces, using maximum likelihood classification and 150 sample points for each class. All bands were used in the classification except for the thermal band due to its spatial resolution. In this study, to examine the spatial pattern of the urban areas in the three periods, the classes were reclassified into built-up and non-built-up areas. To accomplish this task, the images were first reclassified into artificial fields and other classes, and later, roads were eliminated from the artificial areas to restrict the built-up class to only residential areas, including housing, commercial or industrial purposes (because there are road sections that do not include settlements in the surrounding areas and provide only transportation between cities). The images reclassified as built-up and non-built-up areas were edited using auxiliary data. For this purpose, reclassified images were overlaid with several band combinations of satellite images, aerial photographs, and maps and misclassified pixels were edited manually by visual inspection. The final accuracy was increased by this process. The accuracies of the built-up layers were checked using 300 test points for built-up and non-built-up areas in 1989, 2000 and 2013. The kappa values are $0.80,0.82$ and 0.85 for the years 1989, 2000 and 2013, respectively. All kappa values are greater than 0.80 , and an accuracy greater than 0.80 shows strong to perfect agreement, as indicated by Zheng et al. (2015). Binary images of the built-up areas and non-builtup areas from 1989, 2000 and 2013 are shown in Figure 3 in the Results section.

\subsection{Shannon's entropy and urban sprawl}

Shannon's entropy measures the degree of spatial concentration and dispersion of the surface (Tewolde, Cabral 2011). Relative entropy can be used to scale the entropy value into a value that ranges from 0 to 1 and can be computed using Eq. (1) (Sun et al. 2007; Bhatta et al. 2010b). The distribution of the built-up areas has a maximum compactness (concentrated, aggregation) in one region if the value of entropy is 0 , and the value is 1 when the built-up area has an unevenly dispersed spatial distribution (Tewolde, Cabral 2011). The halfway mark is generally considered the threshold (Bhatta et al. 2010b; Alsharif et al. 2015). If the entropy value crosses this threshold (0.5), the city is considered sprawling (Bhatta et al. 2010b):

$$
E_{n}=\sum_{i}^{n} p_{i} \log \left(1 / p_{i}\right) / \log (n),
$$

where $p_{i}=x_{i} / \sum_{i}^{n} x_{i}$ and $x_{i}$ is the density of land development, which is equal to the amount of built-up land divided by the total amount of built-up land in the $i$ th of $n$ total zones (Tewolde, Cabral 2011; Mohammady, Delavar 2014).

Because the distribution of a geographical phenomenon can be measured and determined using entropy, the difference in the entropy between time $t$ and $t+1$ can be used as an indicator of the magnitude of the change in the urban sprawl by calculating the difference in the dispersity (Eq. (2)) (Yeh, Li 2001):

$$
\Delta E_{n}=E_{n}(t+1)-E_{n}(t),
$$

where $\Delta E_{n}$ is the difference between the relative entropy values from two time periods, $E_{n}(t+1)$ is the relative entropy value at time period $t+1$, and $E_{n}(t)$ is the relative entropy value at time period $t$ (Sun et al. 2007).

In this study, to calculate entropy, concentric rings around the city center with $1-\mathrm{km}$ intervals were created for each district. The central commercial centers shaping urban growth were chosen as the city centers. The study areas were also divided into eight directions (North: N, South: S, East: E, West: W, Northeast: NE, Northwest: NW, Southeast: SE, and Southwest: SW) to examine urban sprawl based on direction.

\subsection{Fractal analysis of urban sprawl using box-counting method}

The notion of "fractal" was introduced by Mandelbrot (1983) and comes from the Latin term "fractus", meaning irregular and fragmented; this term is a general expression for self-similarity (Hirata et al. 1987). Euclidean geometry is meaningful and descriptive for simple geometry but cannot adequately express complex objects. Fractal geometry measures the level of complexity rather than the length, area and volume measurements in Euclidean geometry (Kaya, Bolen 2011).

Fractal objects develop via the repetition of the same principles from small scales to large scales. A similar geometry/development model repeats at different scales (Kaya, Bolen 2011). It is not possible to see the repetition 
of the same geometry at different scales, which is called "self-similarity", in most real-world applications (Green 1998; Kaya, Bolen 2011). Similarly, self-similarity is not often seen in urban areas. Therefore, self-similarity in urban studies should be considered continuity in terms of the spatial organization and level of complexity rather than the presence of similar forms at different scales (Kaya, Bolen 2011).

Quantification of this complexity by only the visual aspects is difficult, and for this reason, the fractal dimension is calculated (de Oliveira et al. 2014). The box-counting dimension can measure pictures that are not self-similar (Green 1998). This method computes the number of cells required to completely cover an object with grids of cells of varying size. Practically, this is performed by superimposing regular grids over an object and counting the number of occupied cells (Morency, Chapleau 2003).

The logarithmic ratio of the change in the number of grids to the change in the grid size gives the fractal dimension values (Eq. (3)) (Peitgen et al. 2004; Kaya et al. 2009):

$$
D_{B}=\left(\log N_{2}-\log N_{1}\right) /\left(\log S_{2}-\log S_{1}\right),
$$

where $D_{B}$ is the fractal dimension based on the box-counting method, $N$ is the box number, and $S$ refers to the box size.

The fractal dimension has a value between 1 and 2 (Terzi, Kaya 2008). Values close to 1 indicate more compact and more sustainable urban areas, and values close to 2 indicate less compact or more sprawling and disperse situations (Torrens, Alberti 2000).

In this study, the fractal values were calculated using 10 different grid positions, and the average of the values obtained according to these grid positions was used. The smallest grid size was selected as $150 \mathrm{~m} \times 150 \mathrm{~m}$ (5 pixels), and the largest pixel size was selected as $1.5 \mathrm{~km} \times 1.5 \mathrm{~km}$ (50 pixels) by taking into account the area of the investigated region and the image pixel size.

\subsection{Graphical comparison of Shannon's entropy value and fractal dimension}

Visualization of data or analysis results is always useful to compare them (Gardener 2014). Graphical representation is the simplest way of the visual inspection. In order to understand the similarities and differences between the results of two or more methods, graphical comparison can be realized (Cleveland et al. 1978). In this study, to compare the results of Shannon's entropy and fractal analysis and to evaluate relationships, a graph showing the changes in entropy and fractal dimensions over the years was created (Fig. 6 in the Result section).

\section{Results}

To better understand the urban sprawl in Atakum, Ilkadim and Canik for the years 1989, 2000, and 2013, the results are discussed separately as built-up areas and urban growth, quantification of urban sprawl using Shannon's entropy, characterization of urban sprawl using fractal analysis and comparison of Shannon's entropy and fractal dimension. Shannon's entropy and the fractal dimension quantify the degree of dispersion and complexity of the urban form, respectively.

\subsection{Built-up areas and urban growth}

The binary images encoded as built-up areas and nonbuilt-up areas that were obtained from satellite images after classification and editing are shown in Figure 3. Figure 3 shows that the coastal area in the eastern part of Atakum was almost filled in the 1989-2000 period; therefore, in the period 2000-2013, urban growth occurred toward the south and southwest direction. In the western part of Atakum, the coastal area was filled during both periods, and spread inland occurred in some places. In the eastern part of Ilkadim, there was a spread from the coast inland in the period 1989-2000, and the section adjacent

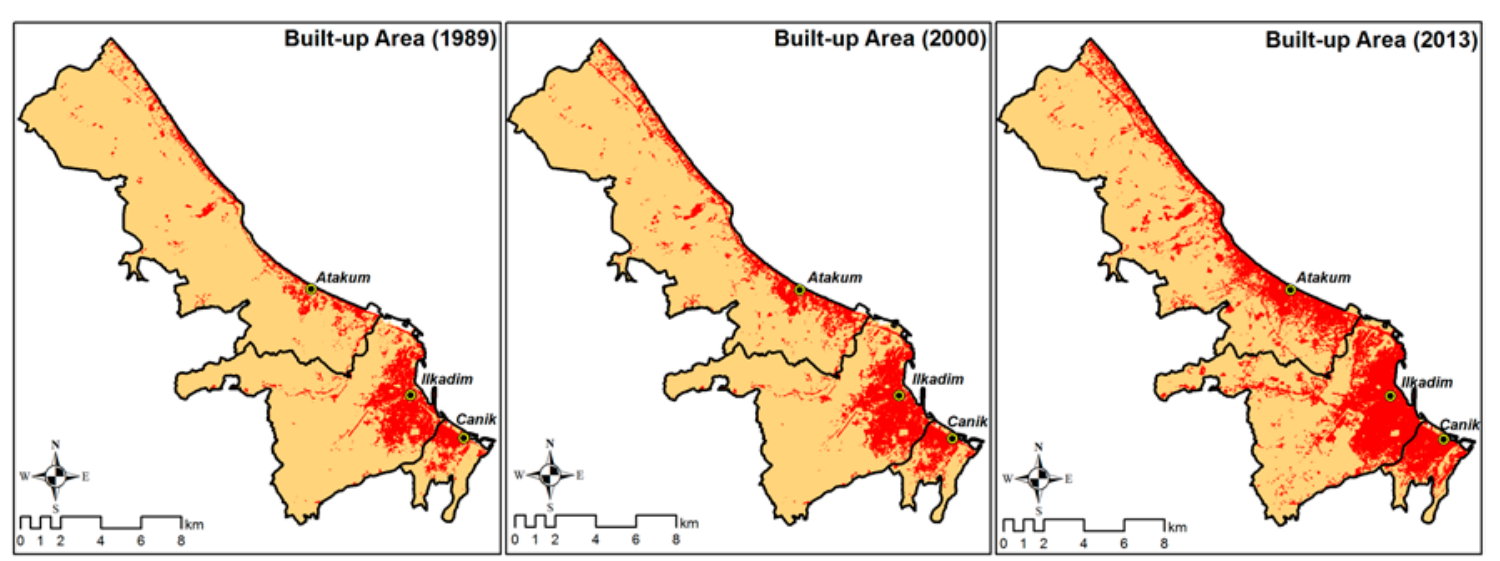

Fig. 3. Built-up and non-built-up areas in Atakum, Ilkadim and Canik for 1989, 2000, and 2013. The coastal areas were increasingly filled with built-up areas between 1989 and 2013, and the spread started inland 
to Atakum was filled with dense settlements in the period 2000-2013. During the same period, a large spread southward was observed in the section of Ilkadim adjacent to Canik. Canik showed a systematic growth in its small area, and the eastern section was completely filled by 2013 .

In Table 1, the total area, built-up area, built-up area annual growth rate (the growth rates were calculated using a logarithmic formula) and change in the built-up area over time are shown for each district. Table 1 shows that urban growth in 2000-2013 was greater than in 19892000. When the three districts were compared, the highest increase in built-up areas was observed in Atakum. The built-up areas, which accounted for $6.10 \mathrm{~km}^{2}$ in 1989 , reached $18.26 \mathrm{~km}^{2}$ in 2013 and approached the total builtup area value in Ilkadim. Considering the percentage increase per district, the largest increase was experienced in Canik, and $57.4 \%$ of the area was built-up in 2013 .

In this study, to calculate the built-up area density at different zones from the center and to calculate Shannon's entropy, concentric rings around city center with intervals of $1 \mathrm{~km}$ were created for each district (Fig. 4a). There are 16, 12, and 4 concentric rings for Atakum, Ilkadim and Canik, respectively. To determine the number of built-up zones, the zone with the outermost built-up area was taken into consideration. Urban density was primarily calculated in these zones, and the differences between zones were evaluated. The changes in the built-up densities in Atakum, Ilkadim and Canik over time are shown in Figure $4 \mathrm{~b}$.

Figure $4 \mathrm{~b}$ shows peaks in zones $1,6,12$, and 15 in Atakum. The reason for the high densities in these zones is that Atakum has sub-centers, which were separate municipalities before 2008. In the graph, Ilkadim has peaks in zones 8 and 10. The reasons for these peaks are industrial facilities and trade settlements in the automotive sector, which extend along the Samsun-Ankara highway. In Can$\mathrm{ik}$, the small area, rough topography, hills and mountains in the southern section caused the dense settlements in a small area. For this reason, Zones 1 and 2 have approximately equal densities.

\subsection{Quantification of urban sprawl using Shannon's entropy}

Shannon's entropy values were calculated at the global level (general scale) using the concentric buffer zones in

Table 1. The changes in the built-up area and built-up area density over time in Atakum, Ilkadim and Canik

\begin{tabular}{|c|c|c|c|c|c|c|c|}
\hline & & 1989 & 2000 & 2013 & $1989-2000$ & $2000-2013$ & $1989-2013$ \\
\hline \multirow{4}{*}{$\begin{array}{l}\text { Atakum } \\
(\text { Total } \\
\text { area }= \\
\left.92.67 \mathrm{~km}^{2}\right)\end{array}$} & Built-up area $\left(\mathrm{km}^{2}\right)$ & 6.10 & 10.09 & 18.26 & & & \\
\hline & Built-up density (\%) & 6.6 & 10.9 & 19.7 & & & \\
\hline & Built-up area growth rate (\%o) & & & & 45.8 & 45.6 & 45.7 \\
\hline & Change in built-up area $\left(\mathrm{km}^{2}\right)$ & & & & 3.99 & 8.17 & $12.16(13.1 \%$ of total area $)$ \\
\hline \multirow{4}{*}{$\begin{array}{l}\text { Ilkadim } \\
(\text { Total } \\
\text { area }= \\
\left.60.18 \mathrm{~km}^{2}\right)\end{array}$} & Built-up area $\left(\mathrm{km}^{2}\right)$ & 10.56 & 12.59 & 20.12 & & & \\
\hline & Built-up density (\%) & 17.5 & 20.9 & 33.4 & & & \\
\hline & Built-up area growth rate $(\%)$ & & & & 16.0 & 36.1 & 26.9 \\
\hline & Change in built-up area $\left(\mathrm{km}^{2}\right)$ & & & & 2.03 & 7.53 & $9.56(15.9 \%$ of total area $)$ \\
\hline \multirow{4}{*}{$\begin{array}{l}\text { Canik } \\
(\text { Total } \\
\text { area }= \\
\left.9.48 \mathrm{~km}^{2}\right)\end{array}$} & Built-up area $\left(\mathrm{km}^{2}\right)$ & 2.61 & 3.32 & 5.44 & & & \\
\hline & Built-up density (\%) & 27.5 & 35.0 & 57.4 & & & \\
\hline & Built-up area growth rate $(\%)$ & & & & 21.9 & 38.0 & 30.6 \\
\hline & Change in built-up area $\left(\mathrm{km}^{2}\right)$ & & & & 0.71 & 2.12 & $2.83(29.9 \%$ of total area $)$ \\
\hline
\end{tabular}

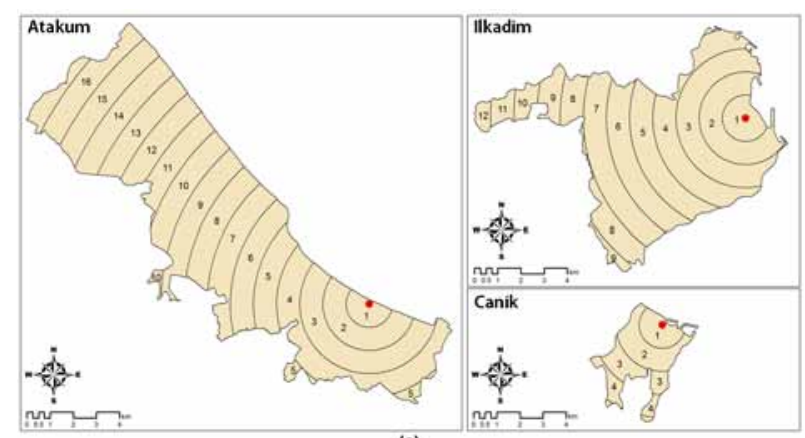

a)

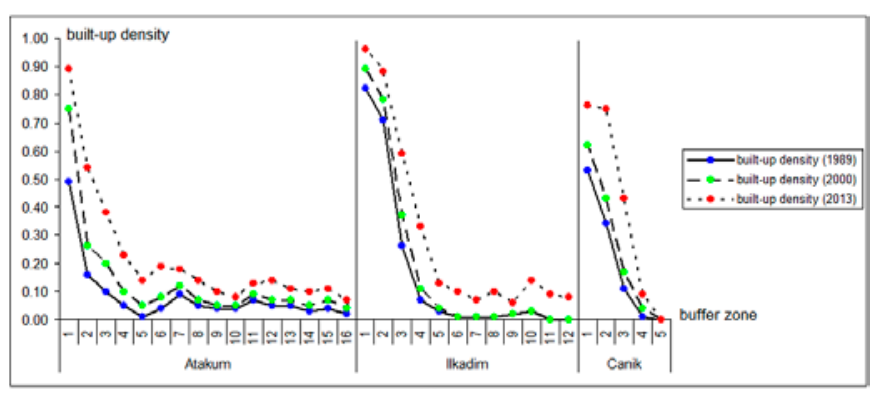

b)

Fig. 4. (a) Circular buffer zones created by the 1-km intervals from the centers of Atakum, Ilkadim and Canik. (b) The changes in the built-up density over time in each buffer zone in Atakum, Ilkadim and Canik 
Figure $4 \mathrm{a}$ and at the direction level using sliced directions. Thus, the study area for each district is partitioned into zones in both circular regions and pie sections.

Urban sprawl can show different characteristics in each direction. A more comprehensive overview of urban sprawl was obtained by using direction-based zones. Table 2 shows the entropy values, which indicate the sprawl rates, for Atakum, Ilkadim and Canik in 1989, 2000 and 2013 and the changes in the entropy values during the periods 1989-2000, 2000-2013, and 19892013. Table 3 shows the entropy values computed for all eight directions.

Table 2 shows that distinct extents of the sprawl were identified for each district, and the entropy values ranged from 0.573 to 0.919 . The highest entropy value was in Atakum, and the lowest entropy value was in Ilkadim for 1989, 2000 and 2013. However, the entropy values showed an increase in Ilkadim and Canik in the 1989-2000 and 2000-2013 periods, while there was no significant change in Atakum. Values close to 0 indicate built-up areas with compact structures, and values close to 1 indicate the presence of spread. The increases in the entropy values in Ilkadim and Canik show that the built-up areas are dispersed and that urban sprawl increased with time. Although no increase was observed in Atakum, Atakum has an entropy value that is close to 1 . Therefore, Atakum has the highest spread for all dates. In addition, the entropy values for all dates in all districts are greater than 0.5 . This case demonstrates that no district has a compact structure, and urban growth has occurred as spread-urban sprawl.

Ilkadim has the lowest entropy value. Accordingly,
Ilkadim has a more compact structure than the other districts. When the amount of change is investigated, it can be seen that the maximum variation occurred in the 2000-2013 period in Ilkadim. However, the entropy changes in Ilkadim are very low in the 1989-2000 period. Similarly, Atakum underwent almost no change in all periods. In Canik, urban sprawl increased in both the 2000-2013 and 1989-2000 periods, but the changes in the period 1989-2000 were much higher.

Table 3 shows that the entropy values are greater than 0.5 in the E, SE, S, SW, W, and NW directions for all dates in Atakum, and the entropy value is lower than 0.5 in only the NE direction for all dates in Ilkadim. The entropy values are greater than 0.5 in the SE, S, SW, W and $\mathrm{NW}$ directions in Canik. In the $\mathrm{N}$ and NE directions from Atakum, there are landfill areas, which have the value of 0 because the built-up areas in landfills cannot sprawl unless landfill areas are extended. The greatest spread (over 0.90) in 1989-2013 occurred in the E and NW directions in Atakum, the N, E, and $\mathrm{W}$ directions in Ilkadim and the SE, S, and NW directions in Canik.

\subsection{Characterization of urban sprawl using fractal analysis}

After application of Shannon's entropy to understand the urban sprawl in terms of urban growth, fractal analysis of the built-up areas was implemented for the analysis of how the urban pattern changed. Because fractal analysis was applied in this study using the box-counting method, the number of cells that coincide with the built-up areas was determined based on the overlap of the grids at different

Table 2. Shannon's entropy for the study area in 1989, 2000 and 2013 and the changes in the entropy over time

\begin{tabular}{lcccccc}
\hline & \multicolumn{3}{c}{$E_{n}$} & \multicolumn{3}{c}{$\Delta E_{n}$} \\
\cline { 2 - 7 } & 1989 & 2000 & 2013 & $1989-2000$ & $2000-2013$ & $1989-2013$ \\
\hline Atakum & 0.919 & 0.913 & 0.912 & -0.006 & -0.001 & -0.007 \\
\hline Ilkadim & 0.573 & 0.579 & 0.735 & 0.006 & 0.156 & 0.162 \\
\hline Canik & 0.710 & 0.766 & 0.800 & 0.056 & 0.034 & 0.090 \\
\hline
\end{tabular}

Table 3. Shannon's entropy in 1989, 2000, and 2013 for all directions

\begin{tabular}{lccccccccccc}
\hline & Year & $\mathrm{N}$ & $\mathrm{NE}$ & $\mathrm{E}$ & $\mathrm{SE}$ & $\mathrm{S}$ & $\mathrm{SW}$ & $\mathrm{W}$ & $\mathrm{NW}$ \\
\hline \multirow{4}{*}{ Atakum } & 1989 & 0.000 & 0.000 & 0.974 & 0.861 & 0.674 & 0.551 & 0.794 & 0.960 \\
\cline { 2 - 10 } & 2000 & 0.000 & 0.000 & 0.989 & 0.863 & 0.643 & 0.619 & 0.841 & 0.980 \\
\cline { 2 - 10 } & 2013 & 0.000 & 0.000 & 0.994 & 0.866 & 0.776 & 0.770 & 0.891 & 0.981 \\
\hline \multirow{3}{*}{ Ilkadim } & 1989 & 0.907 & 0.297 & 0.928 & 0.862 & 0.700 & 0.675 & 0.728 & 0.656 \\
\cline { 2 - 10 } & 2000 & 0.916 & 0.279 & 0.890 & 0.847 & 0.735 & 0.672 & 0.735 & 0.741 \\
\hline \multirow{3}{*}{ Canik } & 2013 & 0.816 & 0.196 & 0.872 & 0.842 & 0.816 & 0.891 & 0.910 & 0.851 \\
\cline { 2 - 10 } & 1989 & 0.000 & 0.000 & 0.000 & 0.999 & 0.750 & 0.800 & 0.729 & 0.965 \\
\hline & 2000 & 0.000 & 0.000 & 0.000 & 1.000 & 0.864 & 0.847 & 0.718 & 0.956 \\
\hline
\end{tabular}


sizes with the built-up layers. As indicated in the sub-section "Fractal analysis of urban sprawl using box-counting method", the fractal values were obtained through box counting with a minimum grid size of $150 \times 150 \mathrm{~m}$ and a maximum size of $1.5 \times 1.5 \mathrm{~km}$. The overlapping of the layers with different box sizes are shown for Canik in Figure 5. The fractal values obtained from average of fractal dimensions calculated using 10 different grid positions are shown in Table 4. The fractal values reveal the fractal dimension of the urban form and represent the landscape complexity. These values, which change between 1 and 2, indicate an increase in shape complexity of the built-up area if they approach 2 and indicate that the built-up area has a more simple form if they approach 1 . Table 4 shows that the complexity of the urban form increased in the 1989-2013 period for each district.

When the fractal values, which show the spatial configuration of the built-up areas in 1989, 2000, and 2013, were examined, increases in the fractal dimensions in Atakum, Ilkadim, and Canik in the 1989-2000 and 2000-2013 periods were found. The fractal dimension was higher in Canik than in the other districts in 1989 and 2000 and was higher in Ilkadim than in the other districts in 2013. Atakum showed the largest increase in fractal dimension in both the 1989-2000 and 2000-2013 periods. Increases in the fractal dimension indicate that the districts have gained a more complex and fragmented structure in every period and the formation of irregular use. Canik showed a regular change, and the 2000-2013 period was more effective in Atakum and Ilkadim. While the fractal value in Atakum was lower than those in Ilkadim and Canik in 1989, the fractal values in the three districts are very close by 2013.

The development areas of urban sprawl reveal the interactions between the compact built-up areas and empty spaces. As mentioned previously, in the case of urban sprawl, the spatial configuration is irregular, dispersed, scattered and fragmented, and sprawl usually exhibits an irregular and self-similar structure (Li 2012), which is why the fractal values can provide important information about the urban sprawl by providing information about the complexity of the urban form. Because the fractal dimension increased and exceeded 1.5 (value in the middle between 1 and 2) in 2013, all districts have transformed from more simple to more complex forms that are scattered and fragmented. This can also be interpreted as the form of urban sprawl (determined by Shannon's entropy) becoming increasingly complex.

\subsection{Comparison of Shannon's entropy and the fractal dimension}

As urban sprawl increases, the fractal dimension increases in Ilkadim and Canik, as seen in the figure generated to examine the relationship between Shannon's entropy and the fractal value (Fig. 6). In Atakum, the Shannon's entropy shows almost no change, while the fractal values increase, and this increase is greater than those in the other districts. These results reveal that there is a relationship between the Shannon's entropy and the fractal dimension for urban sprawl in general but not always. An increase in the fractal dimension even though there is no change in the Shannon's entropy in Atakum can be interpreted as Atakum already having considerably high spread-sprawl properties in all tested periods, but the urban area has continued to grow and the city's fractal structure has changed to a more complex spatial form.

When areal growth and Shannon's entropy values were compared, there was no direct relationship. This can
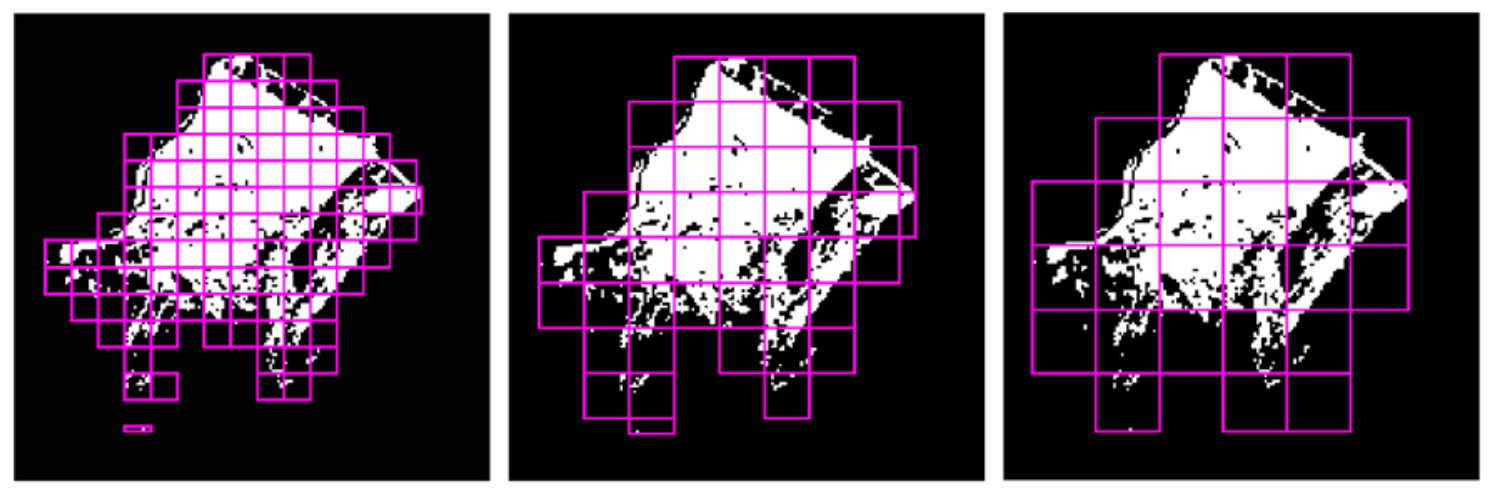

Fig. 5. Overlapping of layers with different box sizes for Canik

Table 4. Fractal values

\begin{tabular}{lccccccccc}
\hline & \multicolumn{3}{c}{ Atakum } & \multicolumn{3}{c}{ Ilkadim } & \multicolumn{3}{c}{ Canik } \\
\hline Year & 1989 & 2000 & 2013 & 1989 & 2000 & 2013 & 1989 & 2000 & 2013 \\
\hline Fractal value & 1.279 & 1.363 & 1.510 & 1.434 & 1.476 & 1.598 & 1.445 & 1.493 & 1.562 \\
\hline Change amount & \multicolumn{2}{c}{0.084} & 0.147 & & 0.042 & 0.122 & & 0.048 & 0.069 \\
\hline
\end{tabular}



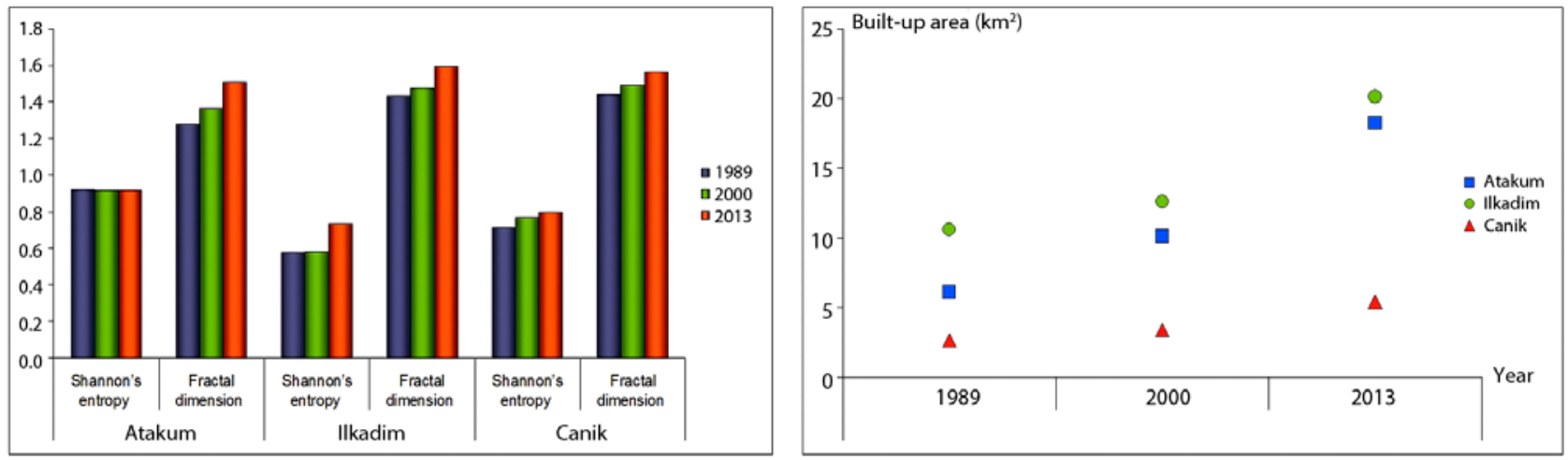

Fig. 6. Changes in built-up area, Shannon's entropy and the fractal dimension - Comparisons

be interpreted as areal growth not always causing urban sprawl. That is, a constant entropy value does not indicate the absence of urban areal growth. When areal growth and the fractal dimension were compared in the study areas, there was a clear relationship between the surface growth and the fractal dimension. As areal growth continued, the fractal dimension increased in all three districts.

Figure 6 shows that built-up areas rapidly increased, and according to Shannon's entropy values, this areal growth showed a dispersed and partitioned structure. Thus, there is urban sprawl in all districts because all entropy values were higher than 0.5 . Although the entropy value in Atakum remained stable, an increase in the fractal value reveals that the form of the urban sprawl in Atakum became increasingly complex. The usefulness of the fractal dimension lies primarily in its aggregate measure of the overall urban form as a fractal (Shen 2002). The increase in the fractal dimension of the entire built-up areas reflects the process of urban space filling in addition to providing information about the complexity of the urban form (Feng, Chen 2010). Therefore, it is understood that, as Atakum, Ilkadim and Canik grew, complex spatial structures formed in the 1989-2013 period.

\section{Discussion}

Prevention of urban sprawl and ensuring sustainable urbanization can only be achieved by correctly determining urban sprawl and understanding the reasons behind it (Li 2012). Every city has a unique and specific urban morphology. These structures were shaped by natural and

Table 5. Population and annual population growth rates in Atakum, Ilkadim and Canik

\begin{tabular}{lccc}
\hline District & 2008 & 2014 & $\begin{array}{c}\text { Population growth } \\
\text { rate (2008-2014) }\end{array}$ \\
\hline Atakum & 107953 & 158031 & $63.5 \% 0$ \\
\hline Ilkadim & 298850 & 308170 & $5.1 \% 0$ \\
\hline Canik & 65724 & 79931 & $32.6 \% 0$ \\
\hline
\end{tabular}

demographic factors, land-use policies and space usage decisions. Samsun, as one of the oldest settlements on the coast of the Black Sea, has remained under intense urbanization pressure and has undergone a rapid anthropogenic change and transformation in recent years (Turkish Ministry of Environment and Urban Planning 2012). When the changes in the urban structures of Atakum, Ilkadim and Canik, which are connected to Samsun and adjacent to each other, were compared, the three districts showed different structures and trends in the changes in the surface area in built-up areas and degree and characteristics of urban sprawl/spread depending on the districts' specific conditions. This disparity mainly characterized the differences in urban growth pattern in Turkey. It was understood that urban form and growth conditions can be very different, even in areas that are physically very close. Even so, when overall assessment is made, the results indicated that the urban area in the three districts has undergone considerable sprawl. This situation reveals that sprawling is a general problem in Turkey as in developing countries.

According to data from 2014 from the Turkish Statistical Institute, population growth was observed in only 4 of the 17 districts of Samsun, and three of the districts were Atakum, Ilkadim and Canik, which were examined in this study. These districts generally experience significant migrant populations from other districts in Samsun and around the province. The boundaries of Atakum, Ilkadim and Canik were finalized in 2008. For this reason, the population data prior $2008 \mathrm{did}$ not conform to the borders of the districts (Ozturk 2015). Therefore, the population and population growth rates (the growth rates were calculated using a logarithmic formula) in the three district areas covered by the study for the assessment for 2008 and beyond are shown in Table 5 (Turkish Statistical Institute 2015).

Table 5 shows that the highest population growth rate and the lowest population growth rate were observed in Atakum and Ilkadim, respectively. The rapid population growth in Atakum and Canik reveals the need for housing to meet this population change. The rate of annual increase 
in built-up areas in the $2000-2013$ period was $45.6 \%$ in Atakum and $38.0 \%$ in Canik (Table 1). Accordingly, the increase in the built-up area was compatible and consistent with the population growth in Atakum and Canik. Population growth is the main cause of urban sprawl. Therefore, population growth in Atakum and Canik can be thought of as the main driving force for the urban sprawl experienced in these districts. The demand for low-cost housing, which is often a result of population growth, has led to the formation of low-density residential areas from the center towards the urban periphery. There are notable differences between the population growth rates and the increases in the built-up areas in Ilkadim: The population growth rate is far below the rate of increase of built-up areas in Ilkadim. In this case, the main cause of the urban sprawl in Ilkadim is the existence of trade, industrial and commercial areas and, thus, the working sector but not population growth. $\mathrm{Li}$ (2012) stated that the growth rate of built-up areas in many metropolises is much higher than that of the urban populations, and the situation in Ilkadim can be explained by this expression because Ilkadim has grown as a center of Samsun.

Highways have become the most important factor in the increase in the built-up area and the urban sprawl in each of the three districts (Fig. 7a). Figure 7a shows that the formation of settlements is along the way. However, the topographies and geometries of the districts also played important roles in the changes, and the districts have shown tendencies to spread in different directions. The linear shape of Atakum caused linear urban growth until 2000; since the 2000s, growth has been realized from

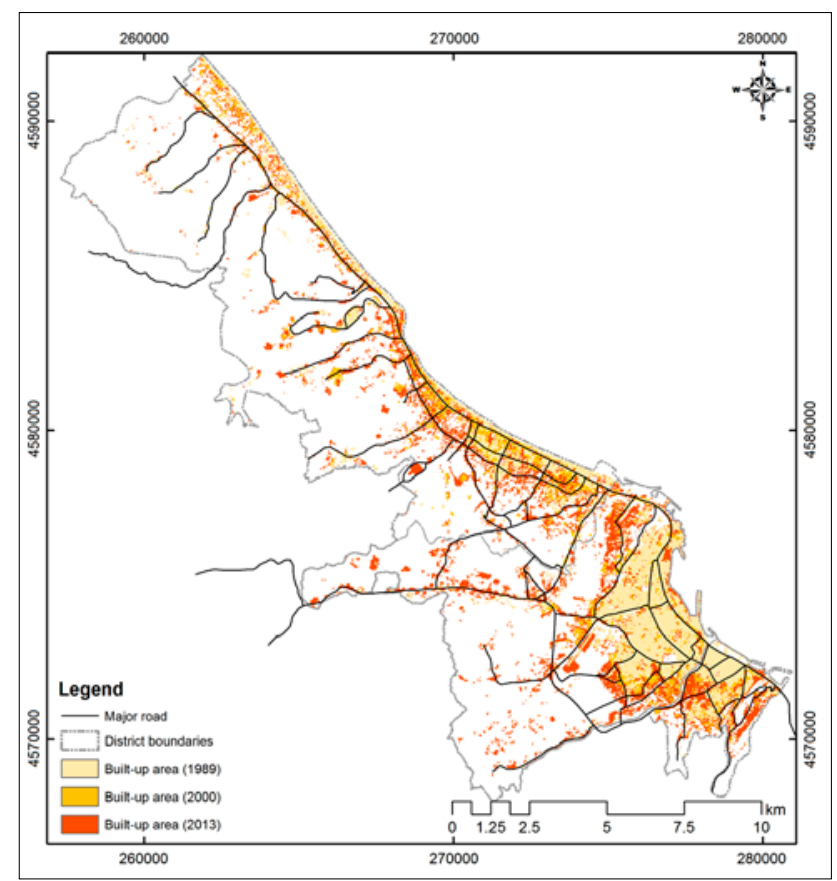

a) the coast inland due to the complete development of the coastal areas.

Shannon's entropy values (0.573-0.919) showed sprawling characteristics similar to Calgary, Alberta, Canada (0.851-0.905 between 1985 and 2001) determined by Sun et al. (2007) and Tripoli, Libya (0.74-0.90 between 1984 and 2010) determined by Alsharif et al. (2015). The fractal values were analyzed, and it was found that they increased in each of the three districts in both the 19892000 and $2000-2013$ periods. This indicates that the complexity of the urban texture gradually increased in all three counties. The fractal value was less than 1.3 in Atakum and was greater than 1.4 in Ilkadim and Canik in 1989. Atakum had a lower fractal value because of its linear urban form compared to Ilkadim and Canik in 1989 and 2000. However, the fractal dimensions of each of the three districts were greater than 1.5 and close to each other in 2013. In studies on urban forms in different countries and counties, the fractal dimensions of urban areas have generally been between 1.3 and 1.8 , and the fractal dimension increased with urban growth (Shen 2002; Mcadams 2007; Terzi, Kaya 2011; Li 2012; Tannier, Thomas 2013; Erdogan, Cubukcu 2014).

The relationship between the change in the fractal value and the Shannon's entropy, which is an indicator of spread, shows that the fractal dimension increased as Shannon's entropy increased in Ilkadim and Canik, but the fractal value increased despite an unchanged Shannon's entropy value in Atakum. As urban sprawl increased, the urban texture of Ilkadim and Canik became increasingly complex. As Atakum experienced urban growth,

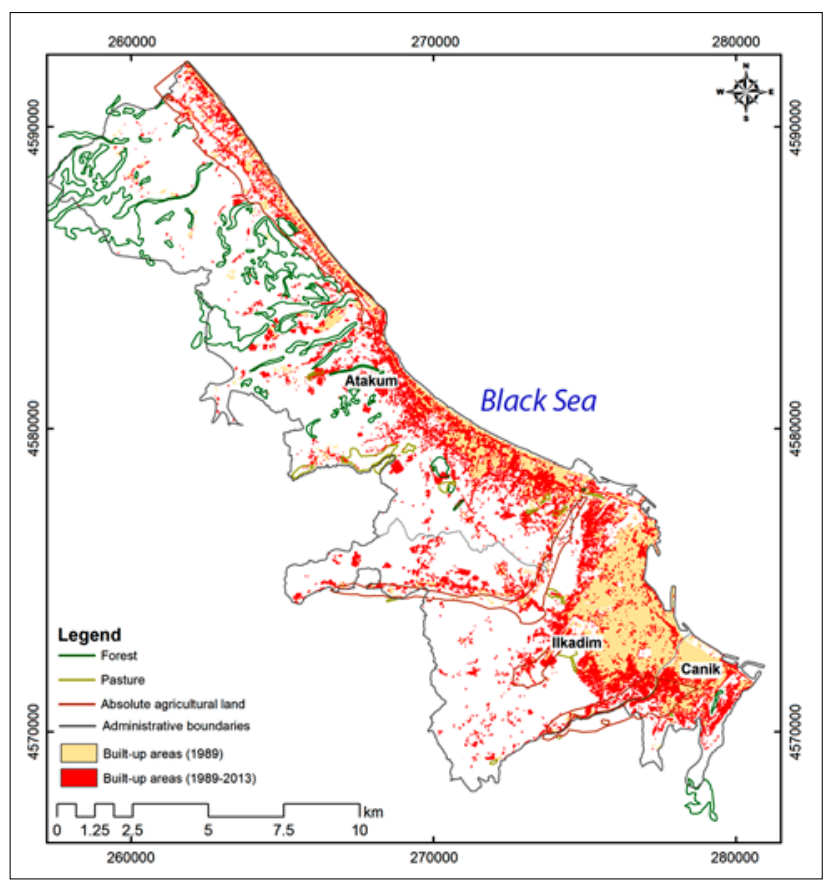

b)

Fig. 7. (a) Spatial distribution of the major road network and extent and distribution of the built-up areas. It can be seen that urban sprawl occurs along roads. (b) The transition to built-up areas via the destruction of forests, absolute agricultural land and pastures 
the urban texture became complex, and the fractal value increased accordingly. However, in Atakum, the entropy value was close to 1 in 1989 and remained stable. The cause of the high value in Atakum can be explained by the existence of sub-centers that grew as municipalities before 2008. Although it is generally expected that the fractal value increases as urban sprawl increases, the findings of the study show that there is not a monotonic relationship between the fractal value and the entropy value. In other words, there is not always a positive linear correlation between them.

The results of this study showed similar results to other studies. Terzi and Kaya (2008, 2011), Kaya et al. (2009) discussed the relationship between the sprawl index and the fractal dimension and indicated that there is a relationship between them, but it is not monotonic and is not always present. In these studies, the fractal dimension of the urban form was positively correlated with the urban sprawl index score when the urban growth pattern was more likely concentrated, but a negative relationship was observed between the fractal dimension and sprawl index score when the urban growth pattern changed from concentrated to semi-linear. Shen (2002) showed that an increase in the fractal dimension can be an indication of an increase in urban areas, but an increase in the fractal dimension is not a measure of the population density. Similarly, Li (2012) found that the measurements in some years showed a positive correlation and the measurements in other years showed a negative correlation between Shannon's entropy and fractal value.

Shannon's entropy and fractal values in the three districts showed that the urban forms are not compact. In addition, while the urban area was increasingly spread and complicated with urban growth in all three districts, agricultural areas, forests and pastures were destroyed as a result of uncontrolled and unplanned growth (Fig. 7b).

When the actual boundary of the forest in 1989 and the officially registered boundaries of the absolute agricultural land and pastures land were compared to the built-up areas constructed between 1989 and 2013, approximately $2.59 \mathrm{~km}^{2}$ absolute agricultural land, $0.10 \mathrm{~km}^{2}$ forests and $0.14 \mathrm{~km}^{2}$ pastures in Atakum; approximately $1.36 \mathrm{~km}^{2} \mathrm{ab}-$ solute agricultural land and $0.03 \mathrm{~km}^{2}$ pasture in Ilkadim; and approximately $0.69 \mathrm{~km}^{2}$ absolute agricultural land was converted into urban use in Canik in the 1989-2013 period. This reveals that, if a city is unable to provide controlled growth and sustainable development, there is a projected increase in the destruction of natural resources.

If an overall assessment is made, it is seen that Shannon's entropy and the fractal dimension provided a very important perspective for assessment of urban growth pattern and urban sprawl. Shannon's entropy value helped to understand the degree of urban sprawl and fractal dimension provided an aspect for complexity of urban form and sprawl pattern. Thus, integrated use of Shannon's entropy and fractal dimension ensures a detailed view on the urban sprawl.

\section{Conclusions}

In this study, the urban sprawl in Atakum, Ilkadim and Canik, which are three adjacent districts in Samsun, Turkey was measured using Shannon's entropy, and the sprawl characteristics were revealed by fractal analysis. This study found that Shannon's entropy and the fractal dimension can be effective for monitoring spatial urban growth dynamics and determined whether there is a relationship among them. The findings of the study reveal that urban sprawl is a problem for Atakum, Ilkadim and Canik and unplanned and uncontrolled growth has caused the destruction of agricultural areas, forests and pastures. For this reason, it is crucial to take necessary measures to control urbanization and to provide sustainable urban management in Atakum, Ilkadim and Canik in particular, but for Turkey in general as in all developing countries. This study also shows that the fractal dimension is not always associated with the entropy value and that urban sprawl is a multifaceted concept that should be investigated using different methods. As a result, it is recommended that in an effort to investigate urban sprawl, Shannon's entropy values should be used to measure the degree of urban sprawl and the fractal value should be used to understand the change in the fractal dimension of the sprawl. Thus, urban sprawl can be evaluated in depth.

\section{References}

Alsharif, A. A. A.; Pradhan, B.; Mansor, S.; Shafri, H. Z. M. 2015. Urban expansion assessment by using remotely sensed data and the relative Shannon entropy model in GIS: a case study of Tripoli, Libya, Theoretical and Empirical Researches in Urban Management 10(1): 55-71.

Atakum Municipality. 2014. Atakum Belediyesi 2015-2019 Stratejik Planı. Atakum, Turkey: Atakum Municipality (in Turkish).

Bhatta, B. 2009. Analysis of urban growth pattern using remote sensing and GIS: a case study of Kolkata, India, International Journal of Remote Sensing 30(18): 4733-4746. https://doi.org/10.1080/01431160802651967

Bhatta, B. 2010. Analysis of urban growth and sprawl from remote sensing data. Chapter 4. Heidelberg: Springer-Verlag, 49-64. https://doi.org/10.1007/978-3-642-05299-6

Bhatta, B. 2012. Urban growth analysis and remote sensing: a case study of Kolkata, India 1980-2010. Chapter 2. Dordrecht: Springer, 9-32. https://doi.org/10.1007/978-94-007-4698-5

Bhatta, B; Saraswati, S; Bandyopadhyay, D. 2010a. Quantifying the degree-of-freedom, degree-of-sprawl, and degree-ofgoodness of urban growth from remote sensing data, Applied Geography 30(1): 96-111. https://doi.org/10.1016/j.apgeog.2009.08.001 
Bhatta, B.; Saraswati, S.; Bandyopadhyay, D. 2010b. Urban sprawl measurement from remote sensing data, Applied Geography 30(4): 731-740. https://doi.org/10.1016/j.apgeog.2010.02.002

Brown, S. R. 1995. Measuring the dimension of self-affine fractals: example of rough surfaces, Chapter 4 in C. C. Barton, P. R. La Pointe (Eds.). Fractals in the Earth Sciences. New York: Plenum Press.

Cleveland, W. S.; Dunn, D. M.; Terpenning, K. J. 1978. A resistant seasonal adjustment procedure with graphical methods for interpretation and diagnosis, Chapter 5 in A. Zellner (Ed.). Seasonal analysis of economic time series. Washington: U.S. Department of Commerce, Bureau of the Census.

de Castro, L. N. 2006. Fractal geometry of nature, Chapter 7 in L. N. de Castro (Ed.). Fundamentals of natural computing: basic concepts, algorithms, and applications. Boca Raton: Taylor \& Francis.

de Oliveira, M. A. B.; Brandi, A. C.; dos Santos, C. A.; Botelho, P. H. H.; Cortez, J. L. L.; de Godoy, M. F.; Braile, D. M. 2014. Comparison of fractal dimension and Shannon entropy in myocytes from rats treated with histidine-tryptophanglutamate and histidine-tryptophan cetoglutarate, Revista Brasileira de Cirurgia Cardiovascular 29(2): 156-62. https://doi.org/10.5935/1678-9741.20140052

Dewan, A. M.; Corner, R. J. 2014. Spatiotemporal analysis of urban growth, sprawl and structure, Chapter 6 in A. Dewan, R. Corner (Eds.). Dhaka megacity: geospatial perspectives on urbanisation, environment and health. Dordrecht: Springer. https://doi.org/10.1007/978-94-007-6735-5_6

District Governorship of Canik. Canik İlçesi [online], [cited 3 May 2015]. Available from Internet: http://www.canik.gov.tr/ (in Turkish).

District Governorship of Ilkadim. İlkadim İlçesi [online], [cited 2 May 2015]. Available from Internet: http://www.ilkadim.gov. $\operatorname{tr} /$ (in Turkish).

Duran, Z.; Musaoglu, N.; Seker, D. Z. 2006. Evaluating urban land use change in historical peninsula, Istanbul, by using GIS and remote sensing, Fresenius Environmental Bulletin 15(8a): 806-810.

Erdogan, G.; Cubukcu, K. M. 2014. Explaining fractal dimension in populous cities, in EURAU 2014-Composite Cities, 12-14 November 2014, İstanbul, Turkey.

Feng, J.; Chen, Y. 2010. Spatiotemporal evolution of urban form and land-use structure in Hangzhou, China: evidence from fractals, Environment and Planning B: Planning and Design 37(5): 838-856. https://doi.org/10.1068/b35078

FRACLAC. 2015. Fractal dimension and lacunarity [online], [cited 15 February 2015]. Available from Internet: http://imagej. nih.gov/ij/plugins/fraclac/fraclac.html

Gardener, M. 2014. Community ecology: Analytical methods using $\mathrm{R}$ and Excel. Pelagic Publishing, Devon, UK.

Green, E. 1998. Fractal Dimension [online], [cited 12 March 2015]. Available from Internet: http://pages.cs.wisc. edu/ ergreen/honors_thesis/dimension.html

Hassan, A. M.; Lee, H. 2015. Toward the sustainable development of urban areas: an overview of global trends in trials and policies, Land Use Policy 48: 199-212. https://doi.org/10.1016/j.landusepol.2015.04.029

Hegazy, I. R.; Kaloop, M. R. 2015. Monitoring urban growth and land use change detection with GIS and remote sensing techniques in Daqahlia governorate Egypt, International Journal of Sustainable Built Environment 4(1): 117-124. https://doi.org/10.1016/j.ijsbe.2015.02.005
Hirata, T.; Satoh, T.; Ito, K. 1987. Fractal structure of spatial distribution of microfracturing in rock, Geophysical Journal of the Royal Astronomical Society 90(2): 369-374. https://doi.org/10.1111/j.1365-246X.1987.tb00732.x

Hsieh, S.-C. 2013. Analyzing urban population data using generalized gamma model and wave-spectrum relation: a case study of Kaohsiung, Computers, Environment and Urban Systems 41: 332-341. https://doi.org/10.1016/j.compenvurbsys.2012.07.005

Hu, S.; Tong, L.; Frazier, A. E.; Liu, Y. 2015. Urban boundary extraction and sprawl analysis using Landsat images: a case study in Wuhan, China, Habitat International 47: 183-195. https://doi.org/10.1016/j.habitatint.2015.01.017

IMAGEJ. 2015. Image Processing and Analysis in Java [online], [cited 15 February 2015]. Available from Internet: http://imagej.nih.gov/ij/index.html

Jaeger, J. A. G.; Schwick, C. 2014. Improving the measurement of urban sprawl: Weighted Urban Proliferation (WUP) and its application to Switzerland, Ecological Indicators 38: 294- 308. https://doi.org/10.1016/j.ecolind.2013.11.022

Jat, M. K.; Garg, P. K.; Khare, D. 2008. Monitoring and modelling of urban sprawl using remote sensing and GIS techniques, International Journal of Applied Earth Observation and Geoinformation 10(1): 26-43.

https://doi.org/10.1016/j.jag.2007.04.002

Kaya, H. S.; Bolen, F. 2011. Kentsel dokudaki değişimin fraktal geometri yöntemiyle incelenmesi, İTÜ Dergisi/A Mimarlik 10(1): 39-50 (in Turkish).

Kaya, H. S.; Terzi, F.; Bolen, F. 2009. Kentsel doku ile şehirsel büyüme biçimi arasındaki ilişkinin mekansal analizi: İstanbul örneği, DEUCBS Coğrafi Bilgi Sistemleri Sempozyumu, CBS ve Bilgi Teknolojileri Bildiriler Kitabı, 10-11 Aralık 2009, İzmir (in Turkish).

Kaya, S; Seker, D. Z.; Tanik, A. 2012. Analysis of urbanized areas using V-I-S components model, Fresenius Environmental Bulletin 21(11): 3243-3248.

Kiran, S.; Joshi, B. 2013. Estimation of variables explaining urbanization concomitant with land-use change: a spatial approach, International Journal of Remote Sensing 34(3): 824847. https://doi.org/10.1080/01431161.2012.720738

Kumar, J. A. V.; Pathan, S. K.; Bhanderi, R. J. 2007. Spatio-temporal analysis for monitoring urban growth - a case study of Indore city, Journal of the Indian Society of Remote Sensing 35(1): 11-20. https://doi.org/10.1007/BF02991829

Li, F. 2012. Investigation of urban sprawl on the basis of remote sensing data: a case study in Jiangning, Nanjing City, China: $\mathrm{PhD}$ Thesis. University of Stuttgart, Germany.

Mandelbrot, B. B. 1983. The fractal geometry of nature. New York: Freeman.

Marsousi, N.; Lajevardi, A. R. 2011. The evaluation of ecological sustainable development capacities in Kashan: an historic city of Iran, in C. A. Brebbia, E. Beriatos (Eds.) Sustainable development and planning $V$. Boston: VIT Press, 371-380. https://doi.org/10.2495/SDP110311

Mcadams, M. A. 2007. Fractal analysis and the urban morphology of a city in a developing country: a case study of Istanbul, Marmara Coğrafya Dergisi 15: 149-172 (in Turkish).

Mesev, T. V.; Longley, P. A.; Batty, M.; Xie, Y. 1995. Morphology from imagery: detecting and measuring the density of urban land use, Environment and Planning A 27(5): 759-780. https://doi.org/10.1068/a270759 
Mohammady, S.; Delavar, M. R. 2014. Urban sprawl modelling. The case of Sanandaj City, Iran, Journal of Settlements and Spatial Planning 5(2): 83-90.

Morency, C.; Chapleau, R. 2003. Fractal geometry for the characterisation of urban-related states: Greater Montreal Case, Harmonic and Fractal Image Analysis - HarFA e-journal, 30-34.

Munafo, M.; Congedo, L. 2013. Assessing urban sprawl in Dar Es Salaam, in International Workshop: Towards Scenarios for Urban Adaptation Planning-Assessing seawater intrusion under climate and land cover changes in Dar es Salaam, Tanzania, 20-22 April 2013, Rome.

Musaoglu, N.; Gurel, M.; Ulugtekin, N.; Tanik A.; Seker, D. Z. 2006. Use of remotely sensed data for analysis of land-use change in a highly urbanized district of mega city, Istanbul, Journal of Environmental Science and Health, Part A: Toxic/ Hazardous Substances and Environmental Engineering 41(9): 2057-2069. https://doi.org/10.1080/10934520600780719

Nason, G. P. 2008. Wavelet Methods in Statistics with R. Chapter 2. New York: Springer, 15-81.

https://doi.org/10.1007/978-0-387-75961-6

Ozturk, D. 2015. Urban growth simulation of Atakum (Samsun, Turkey) using cellular automata-Markov chain and multilayer perceptron-Markov chain models, Remote Sensing 7(5): 5918-5950. https://doi.org/10.3390/rs70505918

Peitgen, H.-O.; Jürgens, H.; Saupe, D. 2004. Chaos and fractals. New frontiers of science. Chapter 4. New York: Springer-Verlag, 183-228. https://doi.org/10.1007/b97624

Ramachandra, T. V.; Bharath, A. H.; Sowmyashree, M. V. 2015. Monitoring urbanization and its implications in a mega city from space: Spatiotemporal patterns and its indicators, Journal of Environmental Management 148: 67-81. https://doi.org/10.1016/j.jenvman.2014.02.015

Ramachandra, T. V.; Bharath, H. A.; Durgappa, D. S. 2012. Insights to urban dynamics through landscape spatial pattern analysis, International Journal of Applied Earth Observation and Geoinformation 18: 329-343. https://doi.org/10.1016/j.jag.2012.03.005

Sarvestani, M. S.; Ibrahim, L., Ab.; Kanaroglou, P. 2011. Three decades of urban growth in the city of Shiraz, Iran: A remote sensing and geographic information systems application, Cities 28(4): 320-329.

http://dx.doi.org/10.1016/j.cities.2011.03.002

Shen, G. 2002. Fractal dimension and fractal growth of urbanized areas, International Journal of Geographical Information Science 16(5): 419-437.

https://doi.org/10.1080/13658810210137013

Sudhira, H. S.; Ramachandra, T. V.; Jagadish, K. S. 2004. Urban sprawl: metrics, dynamics and modelling using GIS, International Journal of Applied Earth Observation and Geoinformation 5(1): 29-39. https://doi.org/10.1016/j.jag.2003.08.002

Sudhira, H. S.; Ramachandra, T. V.; Raj, K. S.; Jagadish, K. S. 2003. Urban growth analysis using spatial and temporal data,
Journal of the Indian Society of Remote Sensing 31(4): 299311. https://doi.org/10.1007/BF03007350

Sun, H.; Forsythe, W.; Waters, N. 2007. Modeling urban land use change and urban sprawl: Calgary, Alberta, Canada, Networks and Spatial Economics 7(4): 353-376. https://doi.org/10.1007/s11067-007-9030-y

Tannier, C.; Thomas, I. 2013. Defining and characterizing urban boundaries: A fractal analysis of theoretical cities and Belgian cities, Computers, Environment and Urban Systems 41: 234248. https://doi.org/10.1016/j.compenvurbsys.2013.07.003

Terzi, F.; Kaya, H. S. 2008. Analyzing urban sprawl patterns through fractal geometry: the case of Istanbul metropolitan area. CASA Working Papers 144. Centre for Advanced Spatial Analysis (UCL), London.

Terzi, F.; Kaya, H. S. 2011. Dynamic spatial analysis of urban sprawl through fractal geometry: the case of Istanbul, Environment and Planning B: Planning and Design 38(1): 75-190. https://doi.org/10.1068/b35096

Tewolde, M. G.; Cabral, P. 2011. Urban sprawl analysis and modeling in Asmara, Eritrea, Remote Sensing 3(10): 2148-2165. https://doi.org/10.3390/rs3102148

Torrens, P. M.; Alberti, M. 2000. Measuring sprawl. CASA Working Papers 27. Centre for Advanced Spatial Analysis (UCL), London.

Turkish Ministry of Environment and Urban Planning. 2012. Samsun Bütünleşik Kıyı Alanları Yönetim ve Planlama Projesi-Mekansal Strateji Planı. Ankara, Turkey: Mekansal Planlama Genel Müdürlüğü (in Turkish).

Turkish Statistical Institute. Statistical Indicators [online], [cited 1 May 2015]. Available from Internet: http://www.tuik.gov.tr/

U.S. Geological Survey. 2015. Earth Explorer [online], [cited 2 March 2015]. Available from Internet: http://earthexplorer. usgs.gov/

Verzosa, L. C. O.; Gonzalez, R. M. 2010. Remote sensing, geographic information systems and Shannon's entropy: measuring urban sprawl in a mountainous environment, in W. Wagner, B. Székely (Eds.). ISPRS TC VII Symposium - 100 Years ISPRS, 5-7 July 2010, Vienna, Austria, ISPRS, Vol. XXXVIII, Part 7A: 269-274.

Wu, H.; Sun, Y.; Shi, W.; Chen, X.; Fu, D. 2013. Examining the satellite-detected urban land use spatial patterns using multidimensional fractal dimension indices, Remote Sensing 5(10): 5152-5172. https://doi.org/10.3390/rs5105152

Yeh, A. G.-O.; Li, X. 2001. Measurement and monitoring of urban sprawl in a rapidly growing region using entropy, Photogrammetric Engineering \& Remote Sensing 67(1): 83-90.

Zeng, C.; He, S.; Cui, J. 2014. A Multi-level and multi-dimensional measuring on urban sprawl: A case study in Wuhan metropolitan area, Central China, Sustainability 6(6): 35713598. https://doi.org/10.3390/su6063571

Zheng, H. W.; Shen, G. Q.; Wang, H.; Hong, J. 2015. Simulating land use change in urban renewal areas: A case study in Hong Kong, Habitat International 46: 23-34. https://doi.org/10.1016/j.habitatint.2014.10.008

Derya OZTURK. Assistant Professor, PhD, Department of Geomatics Engineering, Faculty of Engineering, Ondokuz Mayis University, Samsun, Turkey. In 2009, she completed her doctoral thesis "Determination of Flood Vulnerability using GIS-based Multi-criteria Decision Analysis Methods - A Case Study: South Marmara Basin”. In 2010, she was appointed to an assistant professorship at the Ondokuz Mayis University. She is the author of over 40 scientific papers. Major research interests: geographical information systems, remote sensing, spatial decision support systems, urban growth simulation models, disaster management, coastal management. 